\title{
PENERAPAN APLIKASI SISTEM PENDUKUNG KEPUTUSAN TERHADAP PERKEMBANGAN BALITA BERBASIS ANDROID
}

\author{
Ai Musrifah ${ }^{1}$, Neng Intan Purnama ${ }^{2}$, Sutono ${ }^{3}$ \\ Program Studi Teknik Informatika Fakultas Teknik \\ Universitas Suryakancana ${ }^{1,2,3}$ \\ aimusrifah@unsur.ac.id,intanpurnamasary6@gmail.com, sutono@unsur.ac.id
}

\begin{abstract}
KMS (Kartu Menuju Sehat) is a card to see the development of toddlers that can be monitored by weighing toddlers at the posyandu, where the results of weighing are continuously written in KSM so that each parent can see the development of their toddler. KMS aims to make it easier for health workers and parents to monitor the growth of children under five, find symptoms of growth disorders as early as possible, a means to provide counseling, so that the Posyandu and Puskesmas can easily make decisions about the development of toddlers including the nutritional status of children. In accordance with technological developments, the ease of obtaining information can be faster and more accurate by using an android-based decision support system application that can make it easier for parents and posyandu health workers to make decisions about information about toddler development. The applied application aims to provide convenience in supporting the presentation of information regarding toddler development data, consultation, reminders, and information about toddlers.
\end{abstract}

Keywords: Android, Toddler Development, Decision Support System.

\begin{abstract}
ABSTRAK
KMS (Kartu Menuju Sehat) merupakan kartu untuk melihat perkembangan balita yang dapat dipantau dengan menimbang berat badan Balita di posyandu, dimana secara kontinyu hasil penimbangan ditulis dalam KSM supaya setiap orang tua dapat melihat perkembangan balitanya. KMS bertujuan untuk memudahkan bagian petugas kesehatan dan orang tua memantau pertumbuhan balita, menemukan gejala-gejala gangguan pertumbuhan sedini mungkin, sarana untuk memberikan penyuluhan, sehingga pihak Posyandu maupun Puskesmas mudah dalam mengambil keputusan perkembangan balita meliputi status gizi balita. Sesuai dengan perkembangan teknologi, kemudahan mendapatkan informasi dapat lebih cepat dan akurat dengan menggunakan sebuah aplikasi sistem pendukung keputusan berbasis android yang dapat memudahkan para orangtua dan petugas kesehatan posyandu dalam mengambil keputusan terhadap informasi mengenai perkembangan balita. Aplikasi yang diterapkan bertujuan untuk memberikan kemudahan dalam menunjang penyajian informasi mengenai data perkembangan balita, konsultasi, reminder, dan Informasi seputar balita.
\end{abstract}

Kata kunci : Android, Perkembangan Balita, Sistem pendukung keputusan. 


\section{PENDAHULUAN}

\section{Latar Belakang}

Teknologi informasi yang telah berkembang saat ini dapat membantu memudahkan manusia dalam mengelola informasi secara lebih aktual dan optimal. Penggunaan teknologi informasi bertujuan untuk mencapai efesiensi dalam berbagai jenis kebutuhan pengelolaan informasi, yang menghasilkan kecepatan dan ketepatan waktu pemrosesan, serta ketelitian dan keakuratan informasi. Sistem informasi adalah gabungan yang terorganisasi dari manusia, perangkat lunak, perangkat keras, jaringan komunikasi dan sumber data dalam mengumpulkan, mengubah, dan menyebarkan informasi dalam organisasi ${ }^{1}$. Sistem informasi pada saat ini banyak digunakan dalam kesehatan. Pengembangan sistem informasi yang baru saat ini adalah sebuah aplikasi perkembangan balita menggunakan Sistem Pendukung Keputusan (SPK) yaitu sebuah sistem yang mampu memberikan kemampuan pemecahan masalah maupun kemampuan pengkomunikasian untuk masalah dengan kondisi semi terstruktur dan tak terstruktur ${ }^{2}$. Dalam sistem pendukung keputusan untuk perkembangan balita ini menggunakan metode Logika Fuzzy merupakan suatu metode untuk mewakili adanya ketidakpastian yang menyertai data yang diterima atau informasi sebagai hasil pengelohan data ${ }^{3}$. Keunggulan metode fuzzy Sugeno adalah proses pengambilan keputusan penilaian akan lebih tepat karena didasarkan memiliki toleransi terhadap data-data yang tidak tepat ${ }^{4}$. Menurut Agus Fadlun Niam suatu aplikasi perkembangan balita menggunakan metode Fuzzy sugeno pada sistem pendukung keputusan bertujuan untuk menentukan pertumbuhan balita dengan total akurasi sebesar $72 \%$ meliputi beberapa variabel seperti umur, jenis kelamin, tinggi badan, dan berat badan, sehingga sistem pendukung keputusan menggunakan metode Fuzzy sugeno dalam perkembangan balita dapat membantu mengontrol gizi yang dibutuhkan oleh balita serta menangani pertumbuhan pada balita ${ }^{5}$. Posyandu adalah suatu forum komunikasi, alih tehnologi dan pelayanan kesehatan masyarakat yang mempunyai nilai strategis untuk pengembangan sumber daya manusia sejak dini. Posyandu juga merupakan tempat kegiatan terpadu antara program Keluarga BerencanaKesehatan di tingkat desa. Posyandu adalah pusat kegiatan masyarakat dalam upaya pelayanan kesehatan dan keluarga berencana. Posyandu adalah pusat pelayanan keluarga berencana dan kesehatan yang dikelola dan diselenggarakan untuk dan oleh masyarakat dengan dukungan teknis dari petugas kesehatan dalam rangka pencapaian NKKBS (Norma Keluarga Kecil Bahagia Sejahtera).

Smartphone adalah telepon pintar yang memiliki kemampuan seperti komputer. Smartphone diklasifikasikan sebagai high end mobile phone yang dilengkapi dengan kemampuan mobile computing. Dengan kemampuan mobile computing

\footnotetext{
${ }^{1}$ K. C. Laudon, (2007). Sistem Informasi Manajemen. Palgrave: Basingstoke.

Turban, J. E, (2001). Decision Support Systems and Intelligent Systems. NJ: Prentice Hall.

Jacquin, AP., dan Shamseldin, A.Y, (2009). Review of the application on fuzzy interence in river flow forecasting. Jurnal of Hydroinformatics IWA Publishing.

4 Kusumadewi, S. et al. 2006. Fuzzy Multi-Attribute Decision Making (FUZZY MADM). Graha Ilmu. Yogyakarta

5 Lotfi A. Zadeh, (1965). Fuzzy Set. "Fuzzy Sets". Information and Control.
} 
tersebut, smartphone memiliki kemampuan yang tidak bisa dibandingkan dengan ponsel biasa. Penggunaan Smartphone di zaman sekarang sudah semakin meningkat, untuk pemanfaatan alat tersebut, maka kami akan menerapkan sebuah aplikasi yang dapat diterapkan pada Android sebagai alat pengambilan keputusan terhadap perkembangan balita yang dapat memberikan informasi mengenai data perkembangan balita, konsultasi, reminder, dan Informasi seputar balita.

\section{METODE}

Metode pelaksanaan ada dua tahapan, yaitu:

\section{Tahapan Administrasi}

Pada tahapan ini adalah melaksanakan survey dan izin kepada pihak yang berwenang, yaitu diawali kunjungan ke Puskesmas tanggeng. Kemudian dilanjutkan analisis terhadap kondisi plaksanaan kegiatan posyandu.

2. Tahap Pelaksanaan

Pada tahapan ini adalah dimana proses sosialisasi aplikasi kepada pengurus posyandu dan para anggota orang tua yang memiliki balita. Soasialisasi diawali dengan mengimplementasikan aplikasi dengan cara menginstalkan aplokasi ke smartphone milik pengurus posyandu sebagai admin dalam aplikasi dan kepada para anggota orang tua. Tata cara install aplikasi yaitu dengan cara:

a. Aplikasi disebar melalui group whatshap posyandu setelah itu orangtua mendowload apk supaya bisa install aplikasi dengan kondisi terhubung dengan internet.

b. Install aplikasi Perkembangan balita dengan mengetuk Install. Nanti akan muncul menu untuk menyetujui syarat dan kondisi juga. Ketuk saja pada pilihan Accept atau Menerima

c. Tunggu sampai proses download file installer-nya selesai. Waktu tunggu ini tergantung pada besarnya file installer dan seberapa cepat koneksi internet.

d. aplikasi perkembangan balita sudah siap dijalankan dengan mengklik apk berbentuk android di beranda smartphone.

Setelah itu melakukan pelatihan penggunaan aplikasi tersebut sampai aplikasi dapat dipakai dan dipahami oleh semua peserta.

\section{HASIL DAN PEMBAHASAN}

Posyandu adalah suatu bentuk keterpaduan pelayanan kesehatan yang dilaksanakan di suatu wilayah kerja Puskesmas. Saat ini Posyandu sekar arum yang berada di Kecamatan tanggeung masih terdapat beberapa kendala seperti perkembangan balita sehingga membuat orangtua tidak mengetahui tentang perkembangan balita di karenakan kurangnya suatu informasi mengenai perkembangan balita yang membuat orangtua sulit untuk mengatasi gejala mengenai balitanya sendiri, sulitnya mencari suatu informasi mengenai balita 
seperti info mengenai perawatannya, penyakitnya, serta imunisasinya, ditambah lagi jarangnya orangtua dalam mengamati perkembangan balita seperti tinggi dan berat badan balitannya, kurangnya orangtua memperhatikan waktu makan yang tepat bagi balita, sehingga membuat orangtua lalai dalam perkembangan balita ${ }^{6}$.

Posyandu merupakan salah satu bentuk Upaya Kesehatan bersumber Daya Masyarakat (UKBM) yang dikelola dan diselenggarakan dari, oleh, untuk dan bersama masyarakat dalam penyelenggaraan pembangunan kesehatan, guna memberdayakan masyarakat dan memberikan kemudahan kepada masyarakat dalam memperoleh pelayanan kesehatan dasar untuk mempercepat penurunan angka kematian ibu dan bayi.

Istilah Posyandu yang dikenal sebagai Pos Pelayanan Terpadu adalah suatu tempat yang kegiatannya tidak dilakukan setiap hari melainkan satu bulan sekali diberikan oleh pemberi pelayanan kesehatan dan terdiri dari beberapa pelayanan kesehatan yaitu:

1. Pelayanan Pemantauan Pertumbuhan Berat Badan Balita

2. Pelayanan Imunisasi

3. Pelayanan Kesehatan Ibu dan Anak. Pelayanan Ibu berupa pelayanan ANC (Antenatal Care), kunjungan pasca persalianan (Nifas) sementara Pelayanan Anak berupa Deteksi dan Intervensi Dini Tumbuh Kembang Balita dengan maksud menemukan secara dini kelainan-kelainan pada balita dan melakukan intervensi segera.

4. Pecegahahan dan Penanggulangan diare Dan Pelayanan Kesehatan lainnya ${ }^{7}$.

KMS adalah kartu yang memuat grafik pertumbuhan serta indikator perkembangan yang bermanfaat untuk mencatat dan memantau tumbuh kembang balita setiap bulan dari sejak lahir sampai berusia 5 tahun. KMS juga dapat diartikan sebagai "rapor" kesehatan dan gizi (Catatan riwayat kesehatan dan gizi ) balita.

Di Indonesia dan negara - negara lain, pemantauan berat badan balita dilakukan dengan timbangan bersahaja ( dacin ) yang dicatat dalam suatu sistem kartu yang disebut Kartu Menuju Sehat (KMS).

Indikator BB / U dipakai di dalam Kartu Menuju Sehat ( KMS ) di Posyandu untuk memantau pertumbuhan anak secara perorangan. Pengertian tentang “ Penilaian status Gizi " dan " Pemantauan pertumbuhan "sering dianggap sama sehingga mengakibatkan kerancuan. KMS tidak untuk memantau gizi, tetapi alat pendidikan kepada masyarakat terutama orang tua agar dapat memantau pertumbuhan anak, dengan pesan "Anak sehat tambah umur tambah berat"8.

Android merupakan subset perangkat lunak untuk ponsel yang meliputi sistem operasi, mildware dan aplikasi kunci yang di release oleh google. Saat ini disediakan android SDK (Software Development Kit) sebagai alat bantu dan API

6 Wawancara dengan Bidan, tanggal 15 September 2019 di Posyandu Sekar Arum, jam $11.00 \mathrm{sd}$ selesai

7 Soetjiningsih, (2008). Tumbuh kembang anak. Jakarta

8 Soekirman, (2000). Ilmu Gizi dan Aplikasinya. Jakarta : Direktorat Jendral Pendidikan Tinggi Departemen Pendidikan 
diperlukan untuk mulai mengembangkan aplikasi pada platform android menggunakan bahasa pemrograman java.

1. Activity Manager, untuk mengontrol lifecycle activity, termasuk di dalamnya juga manajemen activity pada aplikasi yang dijalankan. Sebuah aplikasi android dapat terdiri dari beberapa activity.

2. Views, digunakan untuk membangun antarmuka pengguna bagi activity yang digunakan.

3. Notification Manager, digunakan untuk mekanisme sinyal ke pengguna secara kebetulan sesuai dengan waktu yang telah ditentukan.

4. Content Provider, digunakan dalam aplikasi yang dibuat untuk berbagi data.

5. Resource Manager, adanya dukungan terhadap resources atau sumber selain kode program secara umum, seperti string dan gambar9 .

Kebutuhan fungsinal menjelaskan mengenai proses - proses apa saja yang akan dilakukan oleh sistem. Kebutuhan fungsional sistem menggambarkan layanan sistem secara detail. Berkut ini adalah fungsi yang dibutuhkan oleh sistem yang nantinya akan digunakan.

Tabel 1. Kebutuhan Fungsional

\begin{tabular}{|l|l|l|}
\hline No & Kebutuhan Fungsional & Fungsional \\
\hline 1. & Admin & 1. Login \\
& & 2. Gejala balita \\
& & 3. Informasi \\
& & 4. konsultasi \\
& & 5. Pengaturan Akun \\
& & 6. Logout \\
\hline 2. & Orangtua & 1. Login \\
& & 2. Daftar user \\
& & 3. Informasi \\
& & 4. Konsultasi \\
& & 5. Data Perkembangan Balita \\
& & 6. Reminder \\
& & 7. Logout \\
\hline
\end{tabular}

Perancangan struktur menu merupakan gambaran jalur pemakaian Aplikasi Perkembangan Balita yang akan dibangun. Pada struktur menu pemakaian Aplikasi Perkembangan balita terdapat satu bagian struktur menu. Berikut merupakan Struktur Menu dari Perkembangan Balita:

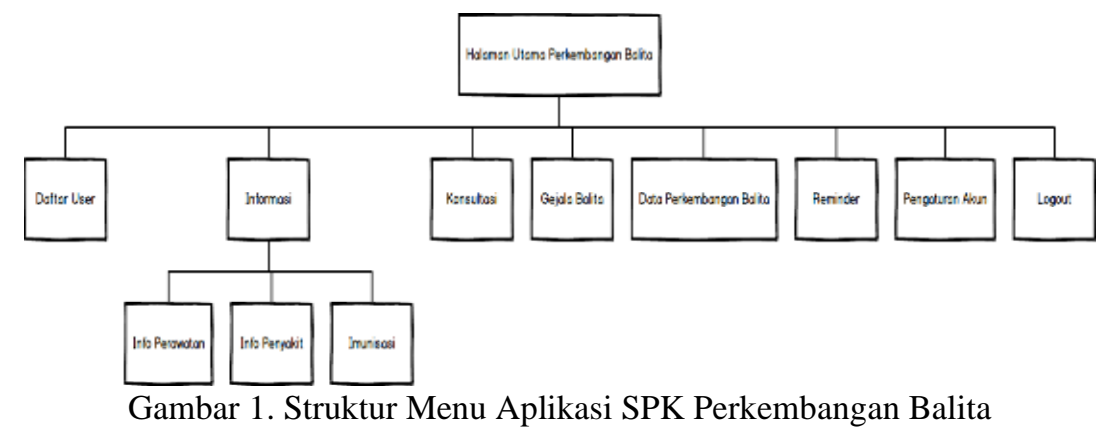

9 Safaat H, Nazrudin, (2000). Pemrograman Aplikasi Mobile Smartphone dan Tablet PC Berbasis Android. Bandung. Informatika 
Bentuk Implementasi Tampilan Aplikasi SPK Perkembangan Balita :

1. Tampilan saat melakukan login.

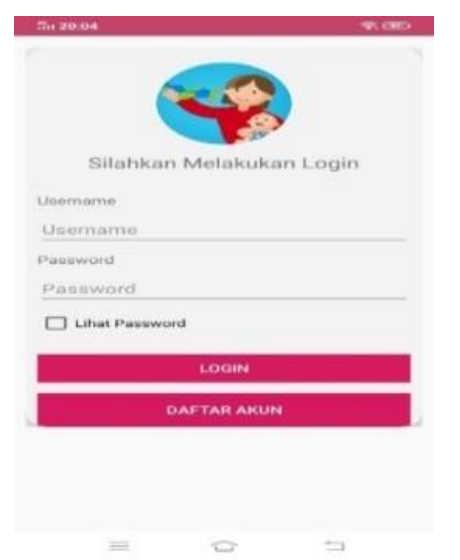

Gambar 1. Implementasi Halaman Login

2. Tampilan Halaman Utama
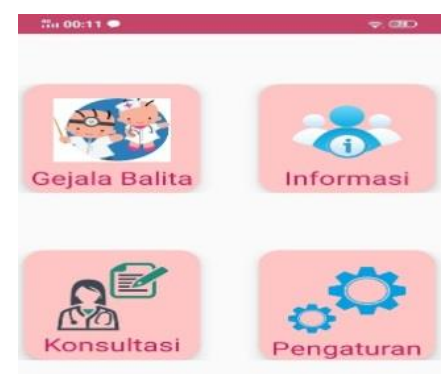

LooOuT

Gambar 2. Implementasi Halaman Utama

3. Tampilan Halaman gejala Balita

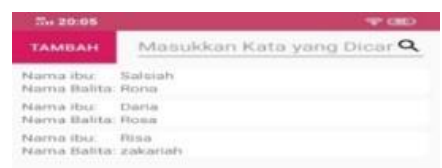

Gambar 3. Implementasi Halaman Gejala Balita 
4. Tampilan Tambah Gejala Balita

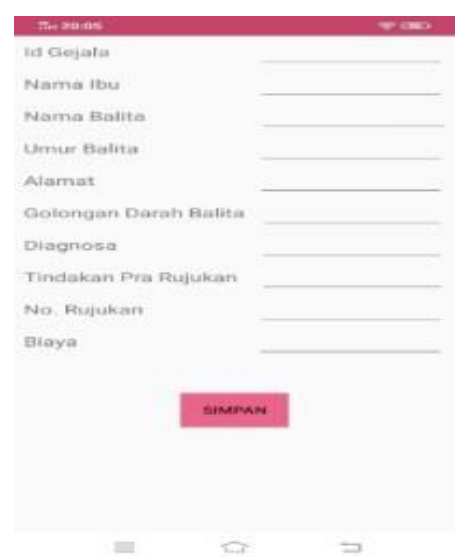

Gambar 4. Implementasi Halaman Tambah Gejala Balita

5. Pesan ketika data akan dihapus.

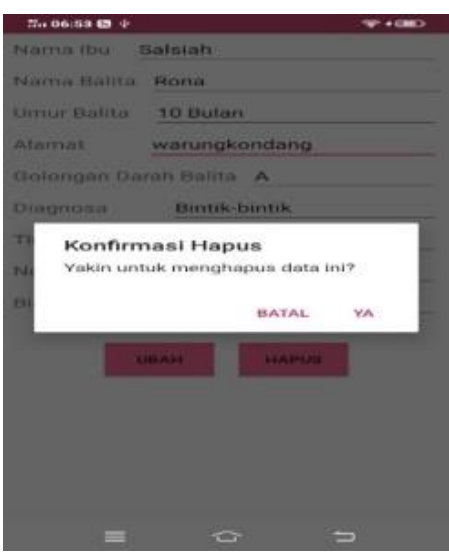

Gambar 5. Implementasi Pesan Hapus Data Balita

6. Pesan ketika gejala balita di ubah.

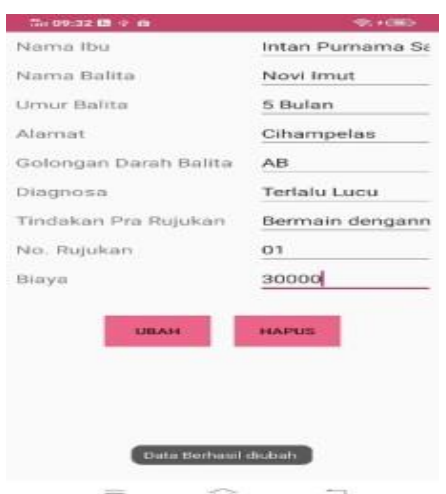

Gambar 6. Implementasi Pesan Gejala balita Diubah 
7. Pesan Gejala Balita di Simpan

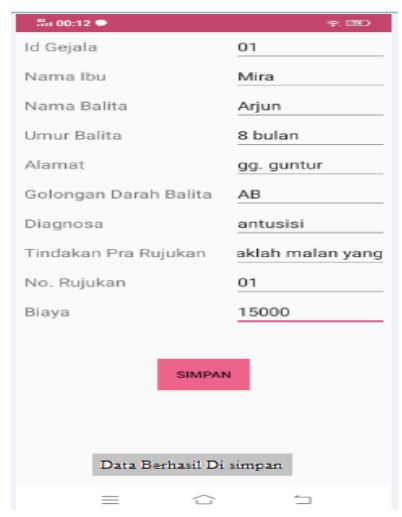

Gambar 7. Implementasi Pesan gejala balita di simpan

8. Tampilan ketika masuk Konsultasi.

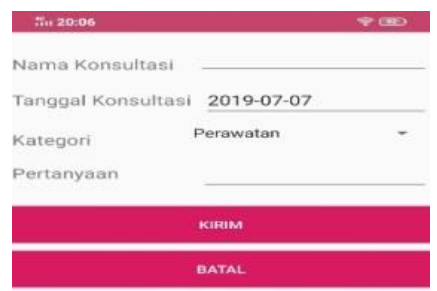

Gambar 8. Implementasi Halaman Konsultasi

9. Pesan Data terkirim.
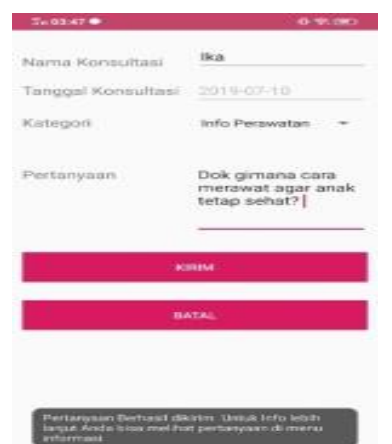

Gambar 9. Implementasi Pesan Data Terkirim 
10. Tampilan ketika masuk

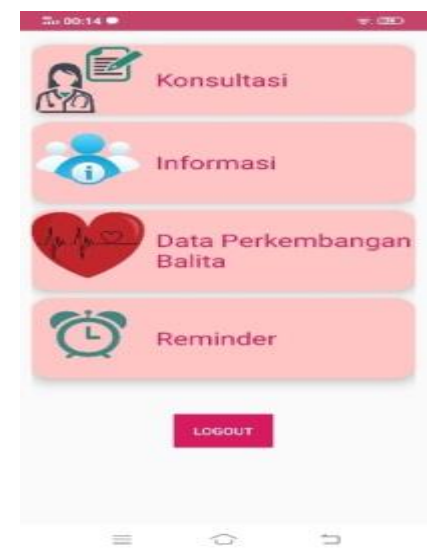

Gambar 10. Implementasi Halaman Utama orangtua

11. Hasil hitung data Perkembangan Balita.

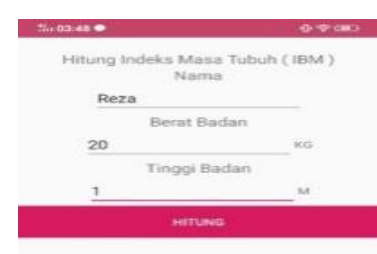

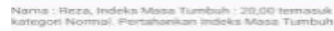

Gambar 21. Implementasi Hasil hitung Data Perkembangan balita

12. Tampilan ketika masuk halaman Reminder

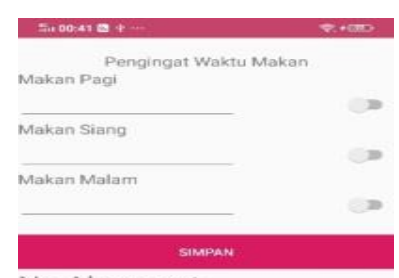

No Alarm set

OPEN TIME PICKER

CanCEL ALARTM

Gambar 12. Implementasi Halaman Reminder 


\section{PENUTUP}

\section{Kesimpulan}

Kesimpulan dari pengabdian di Posyandu Arum Sekar menunjukkan bahwa penggunaan Metode Fuzzy Sugeno dalam Sistem Pendukung Keputusan untuk Perkembangan Balita Berbasis Android Studio dapat dimanfaatkan oleh posyandu Arum Sekar.

Aplikasi yang diterapkan memudahkan dan membantu dalam penyajian informasi mengenai perawatan, penyakit serta imunisasi, dan dapat mengetahui perkembangan masa indeks tubuh pada balita.

\section{Saran}

Aplikasi yang dibuat disarankan bukan hanya dipergunakan oleh posyandu Arum Sekar, tetapi diharapkan semua posyandu yang ada di Kabupaten Cianjur dapan menggunakan aplikasi tersebut

\section{UCAPAN TERIMAKASIH}

Alhamdulillah pe;aksanaan pengabdian telah berjalan dengan lancar sesuai dengan Tujuan yang diinginkan. Terimakasih kami ucapkan kepada Fakultas Teknik dan rekan-rekan yang telah memberikan bantuan dan dukungan demi kelancaran pengabdian ini, tidak lupa kepada Posyandu Arum Sekar yang telah menerima kami untuk dapat mengimplementasikan aplikasi yang kami rancang. Semoga semua kebaikan yang telah kami terima mendapatkan balasan yang setimpal. Aamin Yrb Aalamiin.

\section{DAFTAR PUSTAKA}

Jacquin, AP., dan Shamseldin, A.Y, (2009). Review of the application on fuzzy interence in river flow forecasting. Jurnal of Hydroinformatics IWA Publishing.

K. C. Laudon, (2007). Sistem Informasi Manajemen. Palgrave: Basingstoke.

Kusumadewi, S. et al. 2006. Fuzzy Multi-Attribute Decision Making (FUZZY $M A D M)$. Graha Ilmu. Yogyakarta

Lotfi A. Zadeh, (1965). Fuzzy Set. “Fuzzy Sets”. Information and Control.

Safaat H, Nazrudin, (2000). Pemrograman Aplikasi Mobile Smartphone dan Tablet PC Berbasis Android. Bandung. Informatik.

Soekirman, (2000). Ilmu Gizi dan Aplikasinya. Jakarta : Direktorat Jendral Pendidikan Tinggi Departemen Pendidikan

Soetjiningsih, (2008). Tumbuh kembang anak. Jakarta

Turban, J. E, (2001). Decision Support Systems and Intelligent Systems. NJ: Prentice Hall. 